\title{
Direct sediment transfer from land to deep-sea: Insights into shallow multibeam bathymetry at La Réunion Island
}

\author{
N. Babonneau ${ }^{a, *}$, C. Delacourt ${ }^{a}$, R. Cancouët ${ }^{a}$, E. Sisavath ${ }^{b, c}$, P. Bachèlery ${ }^{b, d}$, A. Mazuel ${ }^{a}$, S.J. Jorry ${ }^{c}$, \\ A. Deschamps ${ }^{a}$, J. Ammann $^{a}$, N. Villeneuve ${ }^{b}$
}

\begin{abstract}
a UMR CNRS 6538 Domaines Océaniques, Université de Brest, UBO, Institut Universitaire Européen de la Mer, Place Copernic, 29280 Plouzané, France

b Laboratoire Géosciences Réunion, Université de La Réunion, UMR CNRS 7154, IPG Paris, 15 avenue René Cassin, BP 7151, 97715 Saint Denis messag Cedex 9, Réunion, France

` Ifremer, Géosciences Marines, Laboratoire Environnements Sédimentaires, BP 70, 29280 Plouzané, France

d Laboratoire Magmas et Volcans, UMR CNRS-IRD 6524, Observatoire de Physique du Globe de ClermontFerrand, Université Blaise Pascal, 5, rue Kessler, 63038 Clermont-Ferrand, France

\author{
*: Corresponding author : Nathalie Babonneau, tel.: + 33298498723 ;
}

email address : $\underline{\text { nathalie.babonneau@univ-brest.fr }}$
\end{abstract}

\begin{abstract}
:
Submarine canyon heads are key areas for understanding the triggering factors of gravity currents responsible for the transfer of detrital sediment to the deep basins. This contribution offers a detailed picture of canyon heads off La Réunion Island, with high-resolution multibeam bathymetry in the water depth range of 4-220 m. The present feeding of the Cilaos turbidite system, one of the largest modern volcaniclastic systems in the world, is deduced from morphological and sedimentological interpretations of newly acquired data. The study highlights small-scale sedimentary features indicating hydrodynamic and sedimentary processes.
\end{abstract}

A direct connexion between the Saint-Etienne river mouth and submarine canyons is evidenced by the complete incision of the shelf and the presence of canyon heads connected to the modern deltaic bar. This direct connection, supplied by river torrential floods (cyclonic floods every two or three years), suggests the continuity of high-density fluvial flows to submarine gravity flows, forming hyperpycnal flows in the canyon.

The initiation of secondary submarine gravity flows by storm waves (large austral waves and cyclonic waves) is also proposed for submarine canyons with large canyon heads developed in the surf zone from a sandy coastal bar. Bedforms in active canyon axis are considered as an indicator of the frequent activity of high-density turbidity currents.

Moreover, a morphological record of last glacial and deglacial sea level variations is preserved, and particularly the Last Glacial Maximum sea level with the presence of small vertical cliffs, observed in this bathymetric data, which likely corresponds to a paleo-shoreline or paleo-reefs.

\section{Highlights}

Sediment transport processes in a submarine canyon head off La Réunion Island $>$ Characterisation of the present feeding of modern volcaniclastic turbidite system $\rightarrow$ A direct morphological connection exists between the river mouth and the canyon - Hyperpycnal flows generated during torrential floods are major processes Large storm waves also play a role in turbidity currents initiation

Keywords: submarine canyon ; canyon head ; turbidity current ; hyperpycnal flow ; coastal instability 


\section{Introduction}

Sediment transfer from land to sea is one of the key processes in the formation of landforms and submarine morphologies. Much of the sediment transport generally occurs during extreme climatic or geological events (floods, earthquakes, storms, volcanic eruptions...) that induce transport of large quantities of sedimentary material to basins during brief repetitive episodes (Korup, 2012). These events can cause significant onshore and offshore morphological changes, particularly in the coastal area, which is highly vulnerable.

Understanding the major morphological changes at land-sea interface and at the seafloor requires a better understanding of sedimentary processes and quantification of sediment flux. From the coast to the deep ocean, one of the main processes of sediment transfer is turbidity current flowing into submarine canyons. Turbidity flows are mostly responsible for submarine erosion of the upper slope and canyon incision. Submarine canyons are mainly located in the continuity of the major drainage networks (Reading and Richards, 1994). Continuity of fluvial sediment fluxes in the canyons is often indirect because of the presence of a shelf and of coastal hydrodynamic settings (waves, tides, currents) that redistribute sediments along the coast.

The origin and the triggering of turbidity currents are still discussed aspects (Piper and Normark, 2009). Scientific issues include the continuity at sea of hyperconcentrated stream flows generating hyperpycnal flows into canyons, mass wasting and re-suspension of sediment deposits under the influence of oceanographic factors (waves, currents).

The study of turbidite processes and their triggering can be addressed in several ways: with the study of modern turbidite systems on the seafloor (Piper and Normark, 2009), with numerical or physical modelling of flow processes (Eke et al., 2011), with monitoring of active currents with current meters and moorings (Johnson et al., 2001; Puig et al., 2003; Liu et al., 2006; Palanques et al., 2006; Puig et al., 2008; Paull et al., 2010;), or the simple observations of communication cable breaks (Heezen and Ewing, 1952; Hsu et al., 2008; Cattaneo et al., 2012). Monitoring and in-situ measurements of turbidity currents are particularly difficult because the gravity events occur occasionally with long recurrence time and their occurrence cannot be anticipated. In addition, the turbidity flows responsible of largest morphological changes are difficult to measure because they damage instruments (Khripounoff et al., 2003; Paull et al., 2003). Only weaker and small-scale turbidity currents can be recorded from in-situ experiments (Xu et al., 2004; Mulder et al., 2012; Xu et al., 2013).

In recent years, high-resolution bathymetric data acquired with latest-generation multibeam and sonar technologies also provides advances in outlining submarine morphological features, and in understanding the sedimentary processes in canyons (Greene et al., 2002; Lastras et al., 2007, Lastras et al., 2009; Mountjoy et al., 2009; Paull et al., 2010; Paull et al.,2013), and especially at the canyon heads (Smith et al., 2007; Yoshikawa and Nemoto, 2010; Casalbore et al., 2011; Lastras et al., 2011).

In this work, the present feeding of the Cilaos turbidite system, one of the largest modern volcaniclastic systems in the world, is deduced from morphological and sedimentological interpretations of a new detailed picture of canyon heads off $\mathrm{La}$ 
Réunion Island. We propose an interpretation of these high-resolution shallow bathymetric data, focused on the head of a submarine canyon (at depths less than $220 \mathrm{~m}$ ) in order to identify sedimentary structures to metric and decametric scales. The Saint-Etienne canyon is located off the Saint-Etienne River at La Reunion. Previous studies showed that the Saint-Etienne canyon feeds the Cilaos turbidite system that extends over the abyssal plain (Saint-Ange et al, 2011; Sisavath et al, 2011). Authors showed that a morphological continuity exists between Saint Etienne River and canyon, suggesting a possible triggering of hyperpycnal currents (SaintAnge et al., 2011). The interpretation of shallow bathymetric data aims to show the detailed structure of the head of the canyon. The link between morphological and structural features that we describe and interpret in this paper, the coastal morphology and sediments (river mouth, beach, coastal erosion) and local hydrodynamic and climatic factors (river floods, waves, cyclone) provides new elements on the issue of land-sea transfer and initiation of turbidity currents at canyon heads.

\section{Regional settings}

La Réunion Island is a volcanic island located in the western Indian Ocean, about $750 \mathrm{~km}$ east of Madagascar. It is the emerged part of an active shield volcano, built on the oceanic crust, and is generally attributed to the surface expression of a hotspot (Duncan et al., 1989).

The subaerial part of La Réunion Island is composed of two main basaltic shield volcanoes: the now extinct Piton des Neiges volcano in the north-western part of the island, and the presently active Piton de La Fournaise volcano in the south-eastern part. The oldest products dated at Piton des Neiges volcano are $\sim 2.5 \mathrm{Ma}$ old basaltic submarine lava flows (Smietana, 2011). Piton des Neiges activity ended around 22 ka (Delibrias et al., 1986), after the emission of differentiated alkalic magmas (Upton \& Wadsworth, 1972). Piton de La Fournaise is a highly active basaltic shield volcano with in average one eruption per year during the last century. A review of the main geophysical and geological characteristics of Piton de la Fournaise volcano can be found in Lenat et al. (2012).

The poorly consolidated nature of young volcanic rocks and breccias, together with a wet tropical climate characterised by frequent tropical storms and cyclones, favour high erosional rates (Louvat and Allegre, 1997) and efficient transport processes through the hydrographic network. Seasonal cyclonic conditions induce torrential rainfalls and floods, causing highly concentrated sediment load in river mouths (Bret et al., 2003; Garcin et al., 2005).

The morphology of the heart of the Piton des Neiges volcano is marked by the existence of large circular depressions, called "cirques". The origin of the "cirques" in La Reunion is generally ascribed to the result of tectonic heritage and intense erosion, expressed by numerous landslides (Oehler et al., 2008; Salvany et al., 2012). The Saint-Etienne River is one of the main rivers on La Réunion Island. The river mouth is located in the south-western coast of the island. Its drainage area covers about $360 \mathrm{~km}^{2}$ and includes the "cirque" of Cilaos and the "Bras de la Plaine" (Fig. 1).

At the river mouth, the whole bed of the Saint-Etienne River is $1.2 \mathrm{~km}$ wide. It presents a braided morphology, with numerous minor channels that are about $10 \mathrm{~m}$ wide. The average solid load is low with about $470000 \mathrm{~m}^{3}$. $\mathrm{yr}^{-1}$ (excluding torrential 
floods), but it can reach $500000 \mathrm{~m}^{3}$ during major flood events and 1-2 millions $\mathrm{m}^{3}$ for centennial flood (Saint-Ange et al., 2011).

At the Saint-Etienne river mouth (Fig. 2), the coastline is formed by fluvial accumulations with poorly sorted deposits dominated by sand, pebbles and boulders that are up to $1 \mathrm{~m}$ in diameter (Saint-Ange et al., 2011). Northwest of the SaintEtienne River mouth, the Etang-Sale beach extends with a pebble bar near the mouth (Fig. 2), evolving to a sandy beach in the western part. The Etang-Sale beach is composed of fine volcanic sand. On land, the Etang-Salé area is characterized by large eolian dunes covering the coastal area, up to an altitude of $\sim 200 \mathrm{~m}$.

South of the Saint-Etienne river mouth, the Pierrefonds coast (Fig. 2) is characterised by outcrops of boulders and pebble fluvial accumulations, partially covered by vegetation.

The effect of tides is low at La Réunion, with an average range of $0.6 \mathrm{~m}(1.1 \mathrm{~m}$ maximum). Three sources of waves contribute to the coastal erosion of the island: the trade-wind waves, the austral-storm waves, and the cyclonic waves (or tropical storm waves) (Fig. 1). The trade-wind waves are small to moderate amplitude (2 to $3.5 \mathrm{~m}$ high) and come from the east and southeast. Austral-storm waves have large wavelengths and high amplitudes ( 3 to $8 \mathrm{~m}$ high). They are strong and form far southwest of the island (south of South Africa). They mainly affect the western and north-western coasts. The cyclonic waves are very high (higher than $4 \mathrm{~m}$ ) and their direction depends on the path of the cyclone or the tropical storm, but most primarily affect the north and east coasts of the island.

The Cilaos deep-sea fan (Fig. 1) is fed by a canyon network as described by SaintAnge et al. (2011) and Sisavath et al. (2011, 2012). Two main canyons incise the submarine slope and correspond to the major feeding of the Cilaos deep-sea fan (Fig. 1): the Saint-Etienne Canyon and the Pierrefonds Canyon (Sisavath et al., 2011). The substrate, wherein canyons incise, is mainly composed of weak volcaniclastic sediments in the coastal area (river mouth and deltaic accumulations) and debris avalanches deposits forming the submarine slope of the island (see Oehler et al. 2008 and Le Friant et al. 2011 for detailed discussion).

\section{Data and methods}

Deep-water bathymetric and backscatter data available on the submarine slope and the abyssal plain around La Réunion Island was acquired during ERODER1 and 2 and FOREVER surveys (2006 and 2008). Maps presented in figure 1 combine backscatter images (Fig. $1 \mathrm{~A}$ ) and swath bathymetry data (Fig. 1B) acquired with Simrad EM12D and EM120. In Figure 1A, high reflectivity corresponds to dark grey and low reflectivity is light grey. Detailed analyses and interpretations of these data set were already published (Le Friant et al., 2011; Saint-Ange at al., 2011; Sisavath et al, 2011; Sisavath et al., 2012; Saint-Ange et al., 2013).

A high-resolution bathymetric dataset of the Saint-Etienne river mouth was collected in December 2009 during the BATHYBAB survey, using a shallow-water multibeam echosounder (RESON SeaBat 8101). This high-resolution $240 \mathrm{kHz}$ multibeam system was temporarily set up on a fishing boat, which allowed acquisition of bathymetric data in water depths ranging from $4 \mathrm{~m}$ up to $220 \mathrm{~m}$ with a vertical resolution of up to $10 \mathrm{~cm}$. Vessel navigation was achieved by PPK (Post-Processed Kinematic) DGPS (Differential Global Positioning System) using reference stations 
located on the coast (maximum baselines of $15 \mathrm{~km}$ ), providing positioning accuracy of a few centimetres. Sound velocity profiles were carried out daily in the vicinity to correct refraction errors. The dataset is tide corrected. Multibeam soundings were edited with QINSy software and provide a $2 \mathrm{~m}$ grid DTM (Figure 2).

Backscatter data are also acquired using the shallow-water multibeam echosounder, but the signal is too attenuated and noisy below $60 \mathrm{~m}$ water depth because of the steep slope and the abrupt slope change in the canyons. The map of reflectivity has been used only for the shallower part (above $\sim 60 \mathrm{~m}$ of water depth). For this data set, the high reflectivity corresponds to light grey tones and the low reflectivity is dark grey (inverse scale to improve visibility).

The multibeam bathymetric survey covers a $2 \times 8 \mathrm{~km}$-long area along the southwestern coast of La Réunion Island (Fig. 2). The survey covers the area off the SaintEtienne River mouth from a depth interval between $4 \mathrm{~m}$ and $220 \mathrm{~m}$ extending from the Etang-Salé beach to the north, and the Pierrefonds coast to the south (Fig. 2).

The $0.5 \mathrm{~m}$ resolution aerial photography, presented in figure 2 , has been acquired by the French Institut Geographique National (@ BDORTHO 2008) in August 2008, six months after the last main cyclonic flood (Gamède cyclone in February 2007).

\section{Results}

\subsection{Morphology of the deep-sea canyons}

Two main canyons feed the Cilaos deep-sea fan: the Saint-Etienne Canyon and the Pierrefonds Canyon (Fig. 1). Canyons are both $4 \mathrm{~km}$ wide with a flat floor and they show a high reflectivity in backscatter imagery (Fig. 1). Two bathymetric profiles, based on ERODER bathymetric data (EM120), are presented in Figure 1. They correspond to the longitudinal depth profile of the Saint-Etienne Canyon axis (black line in figs $1 \mathrm{~B}$ and $1 \mathrm{C}$ ) and the longitudinal depth profile of the interfluve between the Saint-Etienne Canyon and the Pierrefonds Canyon (red line in figs 1B and 1C). This second profile can be considered as a reference profile representing the former slope before canyon incision.

The depth profile of the Saint-Etienne Canyon is smooth and shows a regular bathymetric shape, in comparison with the reference profile, which is irregular down to $2500 \mathrm{~m}$. The maximum vertical incision of the canyon into the submarine slope locally reaches $300 \mathrm{~m}$. The smooth and concave profile of the canyon floor indicates a morphological incision obtained by long-time erosional processes.

The Saint-Etienne canyon is connected to the coast by several tributary canyons (Figs. 1 and 2): a main branch directly in the continuity of the Saint-Etienne river mouth, and secondary tributaries northward (Fig. 1). Southward, the Pierrefonds Canyon is located in front of the paleo-river outlet of the Saint-Etienne River (SaintAnge et al., 2011). A network of narrow tributary canyons feeds the Pierrefonds canyon in the upper slope but there is no connection with the coastal area (Fig. 1).

The figure 2 shows the bathymetric data set acquired during the BATHYBAB survey in 2009 (with colour scale), superimposed on the ERODER data (slope map in grey scale). Despite the data gap existing between the two datasets, there is a good continuity of the sedimentary structures. Canyon tributaries can be prolonged and connected between the two bathymetric maps (red lines in figure 2). 
The shallow bathymetry (BATHYBAB data) shows three separated sectors showing different morphological types: the Etang-Salé sector at North, the Saint-Etienne sector (related to the Saint-Etienne river mouth), and the Pierrefonds sector. The three sectors shows different erosion features and morphological structures, detailed in the following paragraphs.

\subsection{The Etang-Salé sector}

A narrow shelf about $\sim 1$ to $1.5 \mathrm{~km}$ wide is present along the Etang-Salé sector (Fig. 2). The shelf break is located $\sim 115 \mathrm{~m}$ to $120 \mathrm{~m}$ deep and is particularly abrupt, with a steep slope $\left(>30^{\circ}\right)$ and local subvertical walls.

Four major canyons and several minor gullies incise the Etang-Sale shelf (Fig. 2). The overall shelf morphology is smooth and certainly corresponds to sediment accumulation. In the eastern part, the shallow morphology $(<30 \mathrm{~m})$ is characterised by a sediment bar parallel to the coast (Figs. 3 and 7). The canyon heads are characterised by 150 to $200 \mathrm{~m}$ wide curved depressions bounded by scarps (Fig. 7). In shallow water, narrow furrows (decametric size) incise the sediment bar and participate to the feeding of the canyon heads (Fig. 7).

The shelf is characterised by gentle slope $\left(1^{\circ}\right.$ to $\left.2^{\circ}\right)$. At $120 \mathrm{~m}$ water depth, slope abruptly increases up to $30^{\circ}$. Canyons are 20 to $30 \mathrm{~m}$ deep, $150 \mathrm{~m}$ wide with a Ushaped section, and have a flat floor covered by bedforms of $2 \mathrm{~m}$ of amplitude and 30 to $40 \mathrm{~m}$ of wavelength (Fig. 3). Longitudinal bathymetric profiles along the canyons (S4, S5, S6 in figure 3) reveal steps at their upper extremity of the canyons (between 25 and $40 \mathrm{~m}$ water depth). These structures are visible in the bathymetry locally forming successive steps (Fig. 7).

In the deepest part of the shelf, series of gullies incise the shelf break (Figs. 3 and 7). Longitudinal profiles along gullies (S1, S3 in figure 3) show different stages of incision. The incision starts at the shelf break and probably going upward into the shelf, suggesting that gullies correspond to an initial stage in the canyon head formation.

\subsection{The Saint-Etienne sector}

Erosional features dominate the Saint-Etienne sector, with the strong incision of canyons and gullies. Tributary canyons are divided in two networks, converging downward into the Saint-Etienne canyon at $350 \mathrm{~m}$ of water depth (Fig. 2). The northern network locates in front of the river outlet (Figs. 4 and 6). In this area, the highest canyon heads incise the coastal bar of the river, forming a short plateau of $300 \mathrm{~m}$ wide at 10 to $20 \mathrm{~m}$ in water depth (Fig. 6). The canyon heads connected to the Saint-Etienne river mouth have U-shaped sections with incisions about $30 \mathrm{~m}$ deep and $100 \mathrm{~m}$ wide. They show a 30 to $40 \mathrm{~m}$ wide flat axis covered by large crescentshaped bedforms (Fig. 4). These bedforms have approximately $3 \mathrm{~m}$ of amplitude and 15 to $20 \mathrm{~m}$ of wavelength, with well-defined asymmetrical crests perpendicular to the canyon axis.

The southern network shows narrower canyon heads, $\sim 50 \mathrm{~m}$ wide and $\sim 20 \mathrm{~m}$ deep. Canyon flanks and floor are smooth, without bedforms (Fig. 4). The slope along canyon floors ranges from $7^{\circ}$ to $11^{\circ}$. Bathymetric profiles along canyon floors display a break at $\sim 120 \mathrm{~m}$ in depth (S4, S5, S6 in figure 3). The canyon aligned with the most active river channel (S3 in figure 4 ) show the most incised and steep profile. 


\subsection{The Pierrefonds sector}

In Pierrefonds sector, the slope of the canyon floor increases progressively downslope. There is no coastal bar with break in slope as described in the two other sectors. In the upper slope (down to $50 \mathrm{~m}$ of water depth) several successive steps clearly visible in the bathymetric map (Fig. 5).

Canyons are characterised by narrow canyon heads (up to $\sim 50 \mathrm{~m}$ in width) incising the upper slope. Most of them initiate at a depth of $\sim 50$ to $70 \mathrm{~m}$ (Fig. 5). Their longitudinal slope is between 4 and $8^{\circ}$. Unlike other sectors, no bedform is observable in the canyon axis.

\subsection{Analysis of the reflectivity map}

The interpretation of reflectivity data is limited to the shallow area, above $\sim 60 \mathrm{~m}$ of water depth (Fig. 6C). Two main reflectivity facies are identified in the study area.

Facies 1 (Figs. 6C and 6D) is characterised by high reflectivity (light grey). In the proximal area (down to $20 \mathrm{~m}$ ), the surface covered by the facies 1 is particularly irregular and rough. Metric blocs are identifiable in the reflectivity map, indicating the presence of very coarse and bad-sorted sediments, similar to those visible at the river mouth. The roughness decreases at depths greater than $20 \mathrm{~m}$, suggesting a decreasing content of the large particles (blocks and boulders).

Facies 2 (Figs. 6C and 6D) is low to moderate reflectivity. It is visible in the EtangSalé sector and the deep part of the other sectors. Some variations of reflectivity are visible inside this facies, particularly in canyon axis, which are characterised by local higher reflectivity underlining bedforms and steep slope (scarps, canyon walls). The coastal sediments of Etang-Salé sector are dominated by sand accumulation, suggesting that facies 2 is also probably dominated by sand deposits.

In the Saint-Etienne sector, the boundary between the two facies corresponds to the main slope break. The facies 1 corresponds to the coastal bar (Fig. 6) and is limited at the canyon heads incising the bar. Only a small area located in the coastal bar, in front of the main active channel of the river, shows a smooth surface (Fig. 6B) and low reflectivity (Fig. 6D). The contours of this area suggest a gravity instability scar, which could be interpreted as recent erosion and the transport of coarse material toward the canyon head.

\section{Discussion}

\subsection{Sediment feeding and seafloor nature}

Limited data is available on the nature of the seafloor in the ocean basin around La Réunion Island and the submarine slope of the volcanic edifice. In the study area, no core or other sample was collected. However, several cores were collected at the toe of the submarine slope of La Réunion edifice, in the Cilaos turbidite system (Sisavath et al., 2011). Sisavath et al. (2011) showed that turbidite deposits located in the distal lobe are sandy (coarse to medium sand). They also described one sample with 
coarse sand and gravels, collected inside the Saint-Etienne canyon at $2000 \mathrm{~m}$ of water depth.

Moreover, sediment nature (composition and grain size) is also available on land, along the coast, with sandy beaches in the Etang-Sale sector and poorly-sorted alluvial accumulations (dominated by sand, pebbles and boulders) in Saint-Etienne and Pierrefonds sectors.

The interpretation of bathymetric and reflectivity data, acquired during the BATHYBAB survey, provide a first simplified map distinguishing two sedimentary facies (Fig. 6). In the Etang-Sale sector, the coastal bar (up to $25 \mathrm{~m}$ of water depth) is dominated by sandy deposits, probably fed by beach sediment. Sand possibly extends to the uppermost part of the shelf (down to $80 \mathrm{~m}$ ) This interpretation is consistent with the smooth bathymetry and relatively low reflectivity.

In the Saint-Etienne sector, the coastal bar corresponds to the reflectivity facies 1 (Fig. 6). Its composition is probably similar to sediments described in the SaintEtienne riverbed (poorly-sorted alluvial deposits dominated by sand, pebbles and boulders). Below $25 \mathrm{~m}$ of water depth, low reflectivity (facies 2 in figure 6) and smooth morphology in the canyon interfluves suggest sandy accumulations, similar to those observed in the Etang-Salé shelf. The sediment source feeding the canyons is mainly the coastal bar. The very good quality of the data enables us to recognize that boulders are not present in the canyon axis, which are characterised by bedforms. The largest elements (boulders) are probably transferred deeper in the canyon axis during gravity flows. The presence of gravels and sand in the SaintEtienne canyon at $2000 \mathrm{~m}$ water depth (Sisavath et al., 2011) indicates that the sediment is poorly sorted along the canyon axis. In the same way, sediments in canyons axis of the Saint-Etienne sector are probably poorly sorted. Sand, gravels and pebbles, with a low content of boulders, provided by the coastal bar, dominate them.

In the Pierrefonds sector, the morphology of the proximal area $(<60 \mathrm{~m}$ of water depth) is rough and the seafloor reflectivity is high. Morphological steps, visible in the bathymetric map down to $60 \mathrm{~m}$ (Fig. 5), can be interpreted as erosion of thick strata. This sector is identified as the ancient location of deltaic deposits of the Saint-Etienne River (Saint-Ange et al., 2011). The steps probably correspond to the truncated edges of sedimentary layers or interbedded lava flows belonging to this ancient delta. Along the Pierrefonds coast, the sedimentary layers outcropping are composed of riverbed-type deposits (poorly sorted sediments including sand, pebbles and boulders).

\subsection{Origin of canyons in the Saint-Etienne sector}

The feeding zone of the Saint-Etienne canyon shows several types of canyon heads. They can be linked to different types of triggering processes of turbidity currents.

In the Saint-Etienne sector, the morphology of the canyon heads suggests continuity between the fluvial and the submarine morphological structures at the scale of the major riverbed (Fig. 6). The minor river channels are highly mobile in the riverbed, as attested by the strong changes observed for the present channel network after each major flood. Even if channels and canyon heads are not necessarily located in front each other, the number of canyon heads located in front of the riverbed is similar of the number of minor channels of the Saint-Etienne River. The width of canyon heads is narrow (between 20 and $50 \mathrm{~m}$ wide) and corresponds to the width of the minor 
fluvial channels, suggesting continuity from fluvial flows to submarine processes, such as in the case of hyperpycnal flows as suggested by Saint-Ange et al. (2011).

Sedimentary systems able to generate hyperpycnal flows are typically steep, highbedload rivers discharging on narrow shelves (Mulder and Syvitski, 1995; Mulder et al., 2003). The most favourable conditions are present in fan deltas or braid deltas where direct flow of hyper-concentrated bedload provides a mechanism to leave thick gravel and sand beds seaward to the river mouth (Piper and Normark, 2009). The Saint-Etienne River is typically a high-bedload river discharging on a steep submarine slope $\left(>10^{\circ}\right)$. The coastal bar formed by coarse sediment accumulation (blocks and boulders are visible in the bathymetric and reflectivity data in figure 6 ) is too narrow $(\sim 250 \mathrm{~m})$ to store large amount of coarse sediments between the river mouth and the canyon head. Sediment discharge induced by hyper-concentrated stream flows can be directly carried toward the canyon heads in hyperpycnal flows.

The bathymetric profile of the canyon is smooth and continuous up to the canyon head in the Saint-Etienne sector (Figs. 1 and 4 - profile S3), suggesting a profile reaching equilibrium. This sector corresponds to the most incised submarine valley of the study area, and is probably the most active zone in term of sedimentary processes (erosion and transport) regarding the sediment supply of the river.

The littoral of the Saint-Etienne sector, exposed to the south-west, is also affected by high waves generated by austral storms. Canyon heads are located at $20 \mathrm{~m}$ in the coastal bar. At this depth, high waves can rework sediments at the canyon heads and could also generate turbidity currents as observed in other canyons (Xu et al., 2004; Mulder et al., 2012). Contribution of this process is probably minor regarding the huge sediment volume transported during torrential floods. However, during tropical cyclones, the two processes (hyper-concentrated floods and huge waves) can occur together amplifying the efficiency of the sediment transfer to canyons.

\subsection{Origin of canyons in the Etang-Salé sector}

In the Etang-Salé sector, canyons superficially incise the shelf and show enlargement of the canyon heads (Figs. 3 and 7). Main canyon heads are located at 20-25 m of water depth in the coastal bar (interpreted as a sand accumulation). The morphological differences of the canyons of Etang-Salé sector with those of the other sectors suggest that the initiation of gravity currents is different.

In the Etang-Salé sector, there is no direct sediment input from a river. The sand of the Etang-Salé beach is strongly reworked by currents and waves. Large erosion of littoral dunes can be observed on land after events of austral storm waves. Along this sector, storm wave events (consisting of waves generated by austral storm and tropical cyclone) are the main hydrodynamic processes that can erode and transport large amount of sediment. The initiation of submarine gravity flows by storm waves is recognised in submarine canyons crossing narrow shelf and where canyon head is in the surf zone (Piper and Normark, 2009) such as La Jolla and Monterey canyons. The initiation of gravity flows during storms involves re-suspension of sand, and ignition of seaward-advecting flows (Piper and Normark, 2009).

Canyons of the Etang-Salé sector are more spaced and less incised than canyons located in the Saint-Etienne sector (Fig. 3). The frequency of high waves (including austral-storm waves and cyclonic waves) is high at La Réunion with several events per year. For each event, erosional processes are weak and sediment volumes, involved in each gravity flow, are probably limited. It is consistent with the in-situ 
measurements inside the Monterey canyon by Xu et al. (2004), which also show that many of these flows die within the canyon (Paull et al., 2005).

The enlargement of the canyon head in the Etang-Salé sector is located between 20 and $40 \mathrm{~m}$ of water depth (Fig. 3). It could be related to the hydrodynamic processes responsible of the initiation of turbidity current, because the stronger energy of storm wave is limited to bathymetry shallower than $40 \mathrm{~m}$.

Above $20 \mathrm{~m}$ water depth, the coastal bar is locally marked by narrow furrows, which could correspond to superficial imprints of sediment transport by seaward advecting flows resulting from return flows from breaking waves. The $20-40 \mathrm{~m}$ interval is characterised by scarps and steps, suggesting small gravity instabilities, forming the canyon heads. It corresponds to the bathymetric interval where turbidity currents are initiated. Below $40 \mathrm{~m}$, canyon heads narrow and converge forming the main tributary canyons. Canyons were incised by flowing of successive turbidity currents (triggering at the coastal bar).

The various morphologies of canyons and gullies (Fig. 7) reveal possible successive stages of canyon formation in this sector with: (stage 1) a regressive erosion of some gullies from the shelf break, forming the most incised gullies; (stage 2) the capture of turbidity currents coming from the coastal bar by the most incised gullies, forming an initial valley, (stage 3 ) the vertical incision of canyon axis in the shelf by successive turbidity flows initiated by storm waves.

\subsection{Origin of canyons in the Pierrefonds sector}

The upper slope of the Pierrefonds sector ( $<60 \mathrm{~m}$ of water depth) corresponds an erosional surface of the ancient delta of the Saint-Etienne River. Canyon heads are limited to $\sim 60 \mathrm{~m}$ of water depth (Fig. 5). The general morphology of the canyons is relatively smooth (no bedforms) suggesting sediment drape. At present day, the Pierrefonds sector seems less active than the other sectors in term of gravity processes. The slope break located at $\sim 60 \mathrm{~m}$ of water depth could attest to the last activity of turbidity processes in relation with fluvial dynamics. This activity could occur when the Saint-Etienne paleo-river mouth was located at Pierrefonds sector. Regarding the bathymetry of the canyon heads in the Pierrefonds sector, the sea level was $\sim 40-50 \mathrm{~m}$ lower than at present (active canyon heads of the Saint-Etienne sector being at 10-20 m below the present sea-level). These conditions occurred during the last deglacial sea level rise, at $\sim 11$ ka BP (Fairbanks et al., 1989; Bard et al., 1990; Edwards et al., 1993; Hanebuth et al., 2000; Weaver et al., 2003). To validate this hypothesis, it would be necessary to obtain time constrains of the river migration.

\subsection{Origin of bedforms into canyon axes}

Large bedforms have been commonly observed in submarine canyon axes (Wynn et Stow, 2002), for example in the Monterey canyon (Paull et al., 2010) or in the Var channel (Migeon et al., 2012). With wavelengths ranging from $100 \mathrm{~m}$ to $1 \mathrm{~km}$ and amplitude of few meters, they are generally interpreted as sand waves or gravel waves, generated by high-density turbidity currents (Wynn et al., 2002; Wynn et Stow, 2002). Wave crests are aligned perpendicular to the flow direction and wave symmetry is variable. Bedforms are usually interpreted as the product of the combination of erosion and deposition caused by tractive forces. A relationship is 
established between flow velocity, grain size and wave dimensions (Wynn and Stow, 2002).

In the study area off La Réunion Island, bedforms are observed in the canyon axis at water depths between $25 \mathrm{~m}$ and $100 \mathrm{~m}$ in the Saint-Etienne sector and the EtangSalé sector. There are characterised by a crescent shape, wavelengths between 15 and $40 \mathrm{~m}$ and amplitude from 1 to $3 \mathrm{~m}$. At shallow depths $(<350 \mathrm{~m})$, bedforms similar in morphology and size were described in the Monterey canyon (Paull et al., 2010), with wavelengths from 20 to $80 \mathrm{~m}$ and amplitude $\sim 2.5 \mathrm{~m}$. Cores collected in the bedforms of the Monterey canyon axis have shown sandy sequences containing poorly sorted intervals with coarse gravels and clay clasts (Paull et al., 2010). This type of sediment is consistent with our interpretation of sedimentary facies in the canyon axis.

In the Saint-Etienne sector, canyons are narrower and bedforms wavelengths are shorter than in the Etang-Salé sector. The sediment source being coarser in the Saint-Etienne sector (sediments from the river), the morphological differences of canyon axis and bedforms size is probably related to coarser sediments (more abundance of gravel and pebble) and steeper slope, according to the relationship between flow velocity, grain size and wave dimensions (Wynn and Stow, 2002).

In the Monterey canyon, the crescent-shaped bedforms appear to be produced during brief gravity flow events occurring multiples times each year, coinciding with periods of large wave heights (Xu et al., 2008; Paull et al., 2010). The presence of these bedforms in the canyon axis in the Etang-Sale and Saint-Etienne sector could be an indicator of the frequent activity of high-density turbidity currents. At contrary, the absence of bedform in the Pierrefonds sector could indicate the possible inactivity of this sector at present, consistently with the deep location of canyon heads $(>60 \mathrm{~m})$.

\subsection{Shelf break and other slope changes}

Several slope breaks have been identified on the bathymetric sections (Figs 3 and 5), especially in the Etang-Salé and the Pierrefonds sectors, where canyon erosion is weaker than in the Saint-Etienne area.

In the Etang-Sale sector, the shelf is $1.5 \mathrm{~km}$ wide and smooth. The shelf break is well preserved at $120 \mathrm{~m}$ water depth, where subvertical cliffs are identifiable (Fig. 7). The cliffs are few meters high, nearly vertical, and discontinuous due to incisions by canyons and gullies. The value of $120 \mathrm{~m}$ is consistent with the location of the relative sea level during the Last Glacial Maximum (Bard et al., 1990; Yokohama et al., 2000; Clark et al., 2009) and with the data acquired in the Western Indian Ocean (Camoin et al., 2004). The cliffs might correspond to the Last Glacial Maximum paleoshoreline, i.e. from 26.5 ka to 19 to $20 \mathrm{ka}$ (according to Clark et al., 2009). We do not have any information on the lithology of these small cliffs, which may correspond to a beach rock or a paleo-reef, as described in other similar sites (Wiedicke at al., 1999; Berné et al., 2007). This type of geological formation is currently observable along the west and south coasts of La Réunion Island.

In the canyons axes of the Saint-Etienne sector, a similar shelf break at $120 \mathrm{~m}$ water depth is locally preserved as a smooth slope break. Despite the high erosion rate of canyons in this area, gravity flows seem not to have completely erased this presumed paleo-shoreline. 
In addition, the preservation of a Last Glacial Maximum cliffs at $120 \mathrm{~m}$ of water depth would certify that there is no significant subsidence or uplift of this part of La Réunion island since the last $20 \mathrm{ka}$. Although the vertical movement of La Réunion Island is not quantifiable at this timescale, a limited subsidence is consistent with the subsidence rate related to thermal subsidence rate for an oceanic hotspot island, as estimated in Mauritius at $0.03 \mathrm{~mm} \cdot \mathrm{yr}^{-1}$ (Montaggioni and Faure, 1997). On a longer time scale (a few million years), the lack of significant subsidence of La Réunion volcanics is also emphasised by the fact that the lithosphere beneath La Réunion is not significantly flexed, instead of most oceanic volcanic islands, suggesting that another process compensates for the load of the volcanic construction (De Voogd et al., 1999).

Another slope break is visible on the bathymetric sections of the Pierrefonds sector, at $\sim 60 \mathrm{~m}$ water depth (Fig. 5C). It corresponds to the depth of canyon heads and is clearly visible as a step all along the shelf. This step could also correspond to the sea level when river mouth migrated as suggested in the previous paragraphs. However, this interpretation does not explain the lateral continuity of the step along the shelf. Moreover, the gully heads incising the outer shelf of the Etang-Salé area reach up the same water depth (between $60 \mathrm{~m}$ and $70 \mathrm{~m}$ water depth). This well-continuous, slope discontinuity located at $60 \mathrm{~m}$ water depth could have been developed during the Younger Dryas (12.7 to $11.6 \mathrm{ka}$ ), classically interpreted as a decrease in sealevel rise or short-lived sea level stand at about $65 \mathrm{~m}$ below modern sea level (Bard et al., 1990), although some authors also suggested that sea level would have perhaps even fallen (Jorry et al., 2008). Submarine terraces attesting for the Younger Dryas relative sea level have been observed in other areas, like in Mayotte (Camoin et al. 2004).

In La Réunion, the morphological discontinuity observed in Pierrefonds area at $\sim 60 \mathrm{~m}$ water depth seems to correspond to the erosion of paleo-deltaic formations. This step could also correspond to lava flows interstratified in the delta and resisting to erosion. Lava flows are known in the delta area (Saint-Ange et al., 2011) and are outcropping on land. A further determination of the lithology of this layer would be crucial to identify the origin of the submarine morphological step in the Pierrefonds area.

\section{Conclusions}

Feeding areas of submarine canyons are key areas for understanding land-to-sea sediment transfers including the triggering of submarine gravity currents responsible for the transfer of detrital sediments to basins. Detailed morphological study, with high-resolution bathymetry in the water depth range from 5 to $200 \mathrm{~m}$, highlights small-scale sedimentary structures providing information regarding the hydrodynamic and sedimentary processes.

In La Réunion Island, torrential floods generated by tropical cyclones bring large amounts of sediments to the coast. Off the Saint-Etienne River, one of the largest rivers on La Reunion island, sediment transfer form land to sea is particularly efficient, as evidenced by the huge turbidite system existing in continuity with the river and the location at depths less than $25 \mathrm{~m}$ of the heads of submarine canyons.

Our data provide the opportunity to characterize the current functioning of such a system, and to describe the present feeding of the Cilaos turbidite system, one of the largest modern volcaniclastic examples in the world. 
The study area covers three sectors with various submarine morphologies. The Saint-Etienne sector is located in direct continuity with the Saint-Etienne River. It is marked by a dense network of incised canyons up to the coastal bar composed by the coarse and poorly sorted deposits of the river (sand, gravel, boulders). The narrow and incised canyons heads in alignment with river channels suggests that erosion and transport in this area is probably dominated by the activity of hyperpycnal currents.

The Etang-Sale sector is adjacent to the Saint-Etienne sector located off the EtangSalé beach. Sparse canyons incise a shelf of $1 \mathrm{~km}$ wide. The canyon heads widen on a sandy coastal bar at $20 \mathrm{~m}$ depth. Erosional furrows on the coastal bar are induced by storm waves. They feed the canyon heads that are marked by small scarps related to small-scale gravity instabilities. In this sector, the main triggering factor of turbidity currents is the action of storm waves on a predominantly sandy sediment source. Turbidity currents generated in these canyons are probably less concentrated and voluminous than hyperpycnal currents flowing the Saint-Etienne sector, because the morphological impact is much less marked (shallow incision and sparse canyon).

Pierrefonds sector is a less active area in terms of sedimentary processes. Canyon heads are located at $60 \mathrm{~m}$ depth, and are probably not currently supplied with detrital sediment. The proximal area $(<60 \mathrm{~m})$ is characterized by the outcrop of ancient river deposits.

Bedforms are observed in the axis of the canyons considered currently active. Their size indicates hydrodynamic processes and varies with sediment grain size and slope. Bedform wavelength decreases with the increase of the slope and the grain size.

New bathymetric data also show that the shelf break, located at $120 \mathrm{~m}$ depth, is marked by the presence of small cliffs. These cliffs probably correspond to the paleoshoreline or paleo-reef of the Last Glacial Maximum, preserved in the Etang-Salé area. Identification of the cliff lithology and dating are necessary to give a consistent interpretation of these structures.

This study offers a punctual and accurate picture of the canyon heads. Quantification of rapid morphological changes can be achieved by repeated surveying after high storm waves conditions and river torrential floods.

\section{Acknowledgements}

We thank all the partners of this project for their technical and financial supports. French "Ministère de l'Outre-Mer", INSU-CNRS, Région Bretagne (Projet Dyn3D), CG29 and BMO provided funding for BATHYBAB survey. The project also benefits from the support of the Labex Mer (ANR-10-LABX-19-01, IUEM, Brest), the ANR Cocorisco project and the EU through the FP7 project IQmulus (FP7-ICT-2011318787). Thanks are also due to ERODER and FOREVER partners (IFREMER, IPGP), who contribute to the initiation of this project. We also thank the captain of the Charles $V$ fishing boat for his collaboration and $\mathrm{E}$. Delcher for the technical support in La Réunion.

We are gratefull to G. Lastras and an anonymous reviewer for their comments, which significantly contributed to improve the manuscript. 


\section{References}

Bard E., Hamelin, B., Fairbanks, R.G., 1990. U-Th ages obtained by mass spectrometry in corals from Barbados: sea level during the past 130,000 years. Nature 346, 456-458.

Berné S., Jouet, G., Bassetti, M.A., Dennièlou, B., Taviani, M., 2007. Late Glacial to Proboreal sea-level rise recorded by the Rhône deltaic system (NW Mediterranean), Marine Geology 245, 65-88. doi: 10.1016/j.margeo.2007.07.006.

Bret, L., Fevre, Y., Join, J.L., Robineau, B. and Bachèlery, P., 2003. Deposits related to degradation processes on Piton des Neiges Volcano (Reunion Island): overview and geological hazard. Journal of Volcanology and Geothermal Research, 123(1-2), 25-41.

Camoin, G.F., Montaggioni, L.F., Braithwaite, C.J.R., 2004. Late glacial to post glacial sea levels in the Western Ocean, Marine Geology 206, 119-146. doi: 10.1016/j.margeo.2004.02.003.

Casalbore, D., Chiocci, F., Scarascia Mugnozza, G., Tommasi, P. and Sposato, A., 2011. Flash-flood hyperpycnal flows generating shallow-water landslides at Fiumara mouths in Western Messina Strait (Italy). Marine Geophysical Research 32(1), 257-271. doi: 10.1007/s11001-011-9128-y.

Cattaneo, A., Babonneau, N., Ratzov, G., Dan-Unterseh, G., Bracène, R., Mercier de Lépinay, B., Boudial, A., Déverchère, J., 2012. Searching for the seafloor signature of the 21May 2003 Boumerdès earthquake offshore central Algeria. Natural Hazards Earth System Sciences 12, 2159-2172. doi:10.5194/nhess12-2159-2012.

Clark, P.U., Dyke, A.S., Shakun, J.D., Carlson, A.E., Clark, J., Wohlfarth, B., Mitrovica, J.X., Hostetler, S.W. and McCabe, A.M., 2009. The Last Glacial Maximum. Science 325(5941), 710-714.

De Voogd, B., Palome, S., Hirn, A., Charvis, P., Gallart, J., Rousset, D., Danobeitia, J. and Perroud, H., 1999. Vertical movements and material transport during hotspot activity; seismic reflection profiling offshore La Réunion. J. Geophys. Res., B104 (2), 2855-2874.

Delibrias, G., Guiller, M., Labeyrie, J., 1986. GIF natural radiocarbon measurement. Radiocarbon X 28, 64-65.

Duncan, R.A., Backman J, Peterson L, 1989. Reunion hotspot activity through tertiary time: initial results from the Ocean Drilling Program, Leg 115. J. Volcanol. Geotherm. Res 36, 193-198.

Edwards, R.L., Beck, J.W., Burr, G.S., Donahue, D.J., Chappell, J.M.A., Bloom, A.L., Druffel, E.R.M. and Taylor, F.W., 1993. A Large Drop in Atmospheric C-14/C12 and Reduced Melting in the Younger Dryas, Documented with Th-230 Ages of Corals. Science 260(5110), 962-968.

Eke, E., Viparelli, E., Parker, G., 2011. Field-scale numerical modeling of breaching as a mechanism for generating continuous turbidity currents. Geosphere 7 (5), 1063-1076. doi: 10.1130/GES00607.1.

Fairbanks, R.G., 1989. A 17,000-Year Glacio-Eustatic Sea-Level Record - Influence of Glacial Melting Rates on the Younger Dryas Event and Deep-Ocean Circulation. Nature 342(6250), 637-642.

Garcin, M., Poisson, B. and Pouget, R., 2005. High rates of geomorphological processes in a tropical area: the Remparts River case study (Réunion Island, Indian Ocean). Geomorphology, 67(3-4), 335-350.

Greene, H.G., Maher, N.M., Paull, C.K., 2002. Physiography of the Monterey Bay National Marine Sanctuary and implications about continental development. Marine Geology 181, 55-82. 
Hanebuth, T., Stattegger, K. and Grootes, P.M., 2000. Rapid flooding of the Sunda Shelf: A late-glacial sea-level record. Science 288(5468), 1033-1035.

Heezen, B.C., and Ewing, M., 1952, Turbidity currents and submarine slumps, and the Grand Banks earthquake. American Journal of Science 250, 849-873.

Hsu, S.K., Kuo, J., Lo, C.L., Tsai, C.H., Doo, W.B., Ku, C.Y., Sibuet, J.C., 2008. Turbidity currents, submarine landslides and 2006 Pingtung earthquake off SW Taiwan. Terrestrial, Atmospheric and Oceanic Sciences 19, 767-772.

Johnson, K.S., Paull, C.K., Barry, J.P., and Chavez, F.P., 2001. A decadal record of underflows from a coastal river into the deep sea. Geology 29, 1019-1022.

Jorry, S.J., Droxler, A.W., Mallarino, G., Dickens, G.R., Bentley, S.J., Beaufort, L., Peterson, L.C. and Opdyke, B.N., 2008. Bundled turbidite deposition in the central Pandora Trough (Gulf of Papua) since Last Glacial Maximum: Linking sediment nature and accumulation to sea level fluctuations at millennial timescale. Journal of Geophysical Research-Earth Surface, 113(F1). DOI:10.1029/2006jf000649.

Khriponoff, A., Vangriesheim, A., Babonneau, N., Crassous, P., Dennielou, B., and Savoye, B., 2003. Direct observation of intense turbidity current activity in the Zaire submarine valley at $4000 \mathrm{~m}$ water depth. Marine Geology 194, 151158.

Korup O., 2012. Earth's portfolio of extreme sediment transport events. EarthScience Reviews 112, 115-125. doi:10.1016/j.earscirev.2012.02.006.

Lastras, G., Canals, M., Urgeles, R., Amblas, D., Ivanov, M., Droz, L., Dennielou, B., Fabrés, J., Schoolmeester, T., Akhmetzhanov, A., Orange, D., García-García, A., 2007. A walk down the Cap de Creus canyon, northwestern Mediterranean Sea: recent processes inferred from morphology and sediment bedforms. Marine Geology 246 (2-4), 176-192. doi:10.1016/j.margeo.2007.09.002.

Lastras, G., Arzola, R., Masson, D.G., Wynn, R.B., Huvenne, V.A.I., Hühnerbach, V., Canals, M., 2009. Geomorphology and sedimentary features in the central Portuguese canyons, Western Iberian Margin. Geomorphology 103, 310-329. doi:10.1016/ j.geomorph.2008.06.013.

Lastras, G., Canals, M., Amblas, D., Lavoie C., Church, I., De Mol, B., Duran, R., Calafat, A.M., Hughes-Clarcke, J.E., Smith, C.J., Heussner, S., 2011. Understanding sediment dynamics of large submarine valleys from seafloor data: Blanes and la Fonera canyons, northwestern Mediterranean Sea, Marine Geology, 280, 20-39. doi: 10.1016/j.margeo.2010.11.005.

Le Friant, A., Lebas, E., Clément, V., Boudon, G., Deplus, C., de Voogd, B., and Bachèlery, P., 2011, A new model for the evolution of La Réunion volcanic complex from complete marine geophysical surveys: Geophys. Res. Lett., 38, p. L09312.

Lénat J.F., Bachèlery P., and Merle O., 2012. Anatomy of Piton de la Fournaise volcano (La Réunion, Indian Ocean). Bulletin of Volcanology, 74, 1945-1961. doi 10.1007/s00445-012-0640-y.

Liu, J. T., H.-L. Lin, and J.-J. Hung, 2006. A submarine canyon conduit under typhoon conditions off southern Taiwan. Deep-Sea Research I 53, 223-240. doi:10.1016/j.dsr.2005.09.012.

Louvat, P., Allegre, C.J., 1997. Present denudation rates on the island of Reunion determined by river geochemistry: basalt weathering and mass budget between chemical and mechanical erosions. Geochimica et Cosmochimica Acta 61 (17), 3645-3669.

Migeon S., Mulder, T., Savoye B., Sage, F., 2012. Hydrodynamic processes, velocity structure and stratification in natural turbidity currents: Results inferred from field data in the Var Turbidite System. Sedimentary Geology, 245-246, 48-62. doi: 10.1016/j.sedgeo.2011.12007. 
Mountjoy, J.J., Barnes, P.M., Pettinga, J.R., 2009. Morphostructure and evolution of submarine canyons across an active margin, Cook Strait sector of the Hikurangi Margin, New Zealand. Marine Geology 260, 45-68.

Montaggioni, L.F., Faure, G., 1997. Response of reef coral communities to sea level rise: a Holocene model from Mauritius (Western Indian Ocean). Sedimentology, 44, 1053-1070.

Mulder, T., Syvitski, J.P.M., 1995. Turbidity currents generated at mouths of rivers during exceptional discharges to the world oceans. Journal of Geology, 103, 285-299.

Mulder, T., Syvitski, J.P.M., Migeon, S., Faugères J.-C., Savoye, B., 2003. Marine hyperpycnal flows: initiation, behavior and related deposits. A review, Marine and Petroleum Geology, 20, 861-882. doi: 10.1016/j.marpetgeo.2003.01.003.

Mulder, T., Zaragosi, S., Garlan, T., Mavel., J., Cremer, M., Sottolichio, A., Sénéchal, N., Schmidt, S., 2012. Present deep-submarine canyons activity in the Bay of Biscay (NE Atlantic). Marine Geology 295-298, 113-127. doi:10.1016/j.margeo.2011.12.005.

Oehler, J.F., Lenat, J.F. and Labazuy, P., 2008. Growth and collapse of the Reunion Island volcanoes. Bulletin of Volcanology, 70(6), 717-742.

Palanques, A., Martin, J., Puig, P., Guillèn, J., Company, J.B., Sardà, F., 2006. Evidence of sediment gravity flows induced by trawling in the Palamos (Fonera) submarine canyon (northwestern Mediterranean). Deep-Sea Research I 53, 201-214. doi:10.1016/j.dsr.2005.10.003.

Paull, C.K., Ussler, W., III, Greene, H.G., Keaten, R., Mitts, P., and Barry, J., 2003. Caught in the act: the 20 December 2001 gravity flow event in Monterey Canyon. Geo-Marine Letters 22, 227-232.

Paull, C.K., Ussler, W., III, Caress, D.W., Lundsten, E., Barry, J., Covault, J.A., Maier, K.L., Xu, J.P., and Augenstein, S., 2010. Origins of large crescentshaped bedforms within the axial channel of Monterey Canyon, offshore California. Geosphere, 6 (6), 755-774. doi: 10.1130/GES00527.1.

Paull, C.K., Caress, D.W., Ussler, W., III, Lundsten, E., and Meiner-Johnson, M., 2011, High-resolution bathymetry of the axial channels within Monterey and Soquel submarine canyons, offshore central California, Geosphere 7(5), 1077-1101. doi: 10.1130/GES00636.1.

Paull, C.K., Caress, D.W., Lundsten, E., Gwiazda, R., Anderson, K., McGann, M., Conrad, J., Edwards B., Sumner, E.J., 2013. Anatomy of the La Jolla Submarine Canyon system; offshore southern California. Marine Geology 335, 16-34.

Piper D.J.W., Normark, W.R., 2009. Processes that initiate turbidity currents and their influence on turbidites: A marine geology perspective. Journal of Sedimentary Research 79, 347-262. doi: 10.2110/jsr.2009.046.

Puig, P., Ogston, A.S., Mullenbach, B.L., Nittrouer, C.A., Sternberg, R.W., 2003. Shelf-to-canyon sediment-transport processes on the Eel continental margin (northern California), Marine Geology 193, 129-149. doi: 10.1016/S00253227(02)00641-2.

Puig, P., Palanques, A., Orange, D.L., Lastras, G., Canals, M., 2008. Dense shelf water cascading and furrows formation in the Cap de Creus Canyon, northwestern Mediterranean Sea. Continental Shelf Research 28, 20172030.

Reading, H.G., Richard, M.T., 1994. The classification of deep-water siliciclastic deposi- tional systems by grain size and feeder systems. AAPG Bulletin 78, 792-822.

Savoye, B., Cochonat, P., Piper, D.J.W., 1990. Seismic evidence for a complex slide near the Titanic wreck: model of an instability corridor for non-channelised gravity events. Marine Geology, 91, 281-298. 
Saint-Ange, F., Savoye, B., Michon, L., Bachelery, P., Deplus, C., De Voogd, B., Dyment, J., Le Drezen, E., Voisset, M., Le Friant, A., and Boudon, G., 2011. A volcaniclastic deep-sea fan off La Réunion Island (Indian Ocean): Gradualism versus catastrophism, Geology, 39, 271-274. doi: 10.1130/G31478.1.

Saint-Ange F., Bachèlery P., Babonneau N., Michon L., Jorry S., (2013). Volcanoclastic sedimentation on the submarine slopes of a basaltic hotspot volcano: Piton de la Fournaise volcano (La Réunion Island, Indian Ocean). Marine Geology 337, 35-52.

Salvany, T., Lahitte, P., Nativel, P. \& Gillot, P.-Y., 2012. Geomorphic evolution of the Piton des Neiges volcano (Reunion Island, Indian Ocean): Competition between volcanic construction and erosion since 1.4 Ma. Geomorphology 136, 132-147.

Sisavath, E., Babonneau N., Saint-Ange F., Bachèlery P., Jorry S., Deplus C., De Voogd B., Savoye B., 2011. Morphology and sedimentary architecture of a modern volcaniclastic turbidite system: The Cilaos fan, offshore La Réunion Island, Marine Geology, 288, 1-17. doi: 10.1016/j.margeo.2011.06.011.

Sisavath, E., Mazuel, A., Jorry, S., Babonneau, N., Bachèlery P., De Voogd, B., Salpin, M., Emmanuel, L., Beaufort, L., and Toucanne, S., 2012. Processes controlling a volcaniclastic turbiditic system during the last climatic cycle: Example of the Cilaos deep-sea fan, offshore La Réunion Island, Sedimentary Geology 281, 180-193.

Smietana, M., 2010. Pétrologie, géochronologie (K-Ar) et géochimie élémentaire et isotopique $(\mathrm{Sr}, \mathrm{Nd}, \mathrm{Hf}, \mathrm{Pb})$ de laves anciennes de La Réunion: Implications sur la construction de l'édifice volcanique. PhD thesis, University of $\mathrm{La}$ Réunion, $362 \mathrm{pp}$.

Smith, D.P., Kvitek, R., lamietro, P.J., Wong, K., 2007. Twenty-nine months of geomorphic change in upper Monterey Canyon (2002-2005). Marine Geology 236, 79-94. doi: 10.1016/j.margeo.2006.09.024.

Upton, B.G.J., Wadsworth, W.J., 1972. Aspects of magmatic evolution on Re.union island. Philos. Trans. R. Soc. Lond. A 271, 105-130.

Weaver, A.J., Saenko, O.A., Clark, P.U. and Mitrovica, J.X., 2003. Meltwater pulse $1 \mathrm{~A}$ from Antarctica as a trigger of the bolling-allerod warm interval. Science 299(5613), 1709-1713.

Wiedicke, M., Kudrass, H.-R., Hübscher, C., 1999. Oolitic beach barriers of the last Glacial sea level lowstand at the outer Bengal shelf, Marine Geology 157, 718.

Wynn, R.B., Piper, D.J.W., Gee, M.J.R., 2002. Generation and migration of coarsegrained sediment waves in turbidity current channels and channel-lobe transition zones. Marine Geology, 192, 59-78.

Wynn R.B., Stow D.A.V., 2002. Classification and characterisation of deep-water sediment waves. Marine Geology, 192, 7-22.

Xu, J.P., Noble, M.A., and Rosenfeld, L.K., 2004. In-situ measurements of velocity structure within turbidity currents. Geophysical Research Letters 31, L09311. doi: 10.1029/2004GL019718 p.

Xu, J.P., Wong, F.L., Kvitek, R., Smith, D.P. and Paull, C.K., 2008. Sandwave migration in Monterey Submarine Canyon, Central California. Marine Geology, 248 (3-4), 193-212. doi: 10.1016/j.margeo.2007.11.005.

Xu, J.P., Barry, J.P., Paull, C.K., 2013. Small-scale turbidity currents in a big submarine canyon. Geology 41 (2), 143-146. doi:10.1130/G33727.1.

Yokoyama, Y., Lambeck, K., De Deckker, P., Johnston, P. and Fifield, I.K., 2000. Timing of the Last Glacial Maximum from observed sea-level minima. Nature 406, 413-416. 

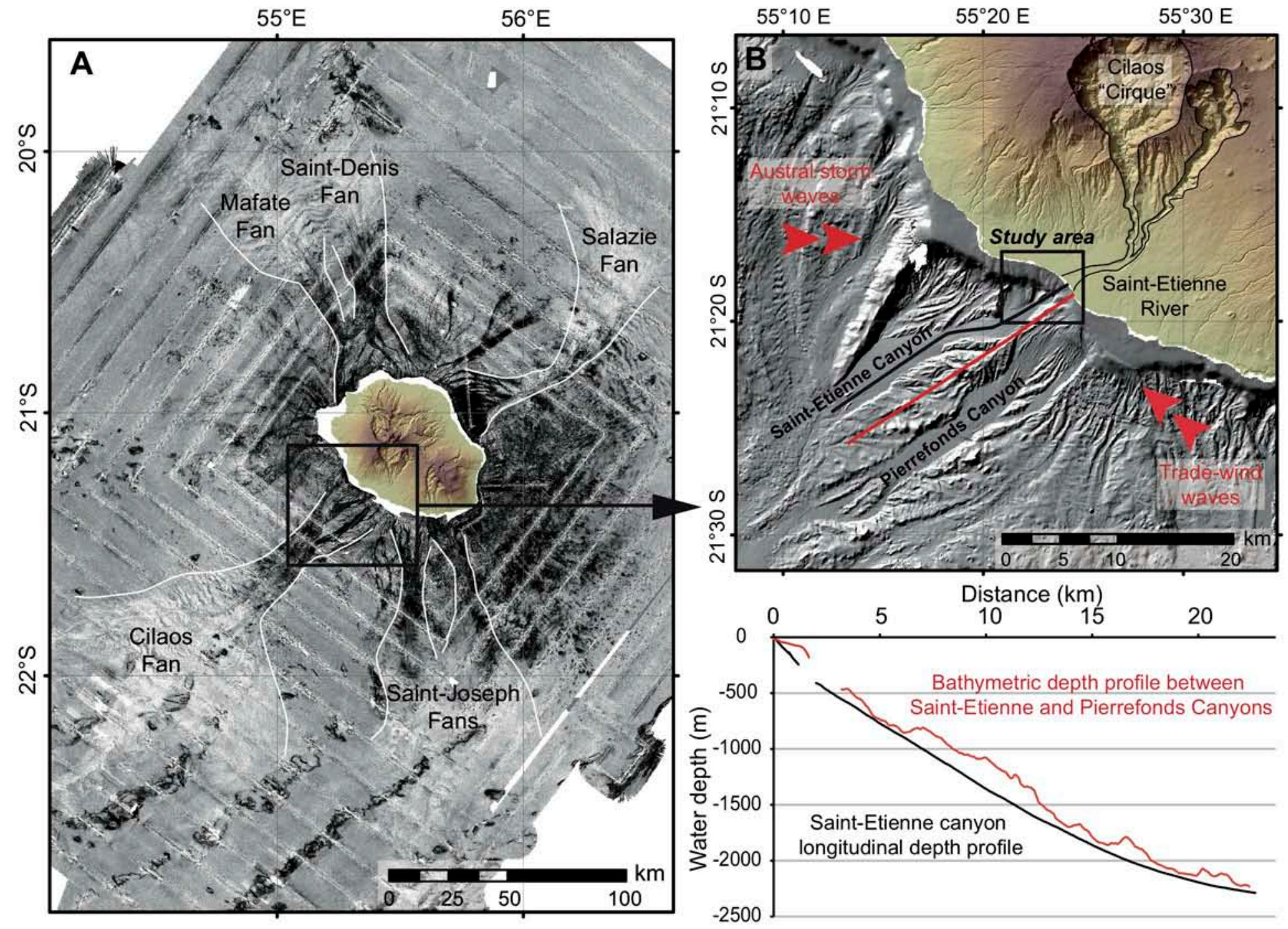

Figure 1. (A) Backscatter image (high reflectivity in black, low reflectivity in white) around La Réunion Island from ERODER and FOREVER data, 2006 (modified after Sisavath et al., 2011), (B) Topography and bathymetry of the upper part of Cilaos sedimentary system including the Cilaos "Cirque", the Saint-Etienne River and the related submarine canyons (shaded bathymetry from ERODER data), and longitudinal depth profiles along the Saint-Etienne Canyon and between the Saint-Etienne Canyon and the Pierrefonds Canyon based on ERODER bathymetric data (from the coast to $2500 \mathrm{~m}$ deep) 


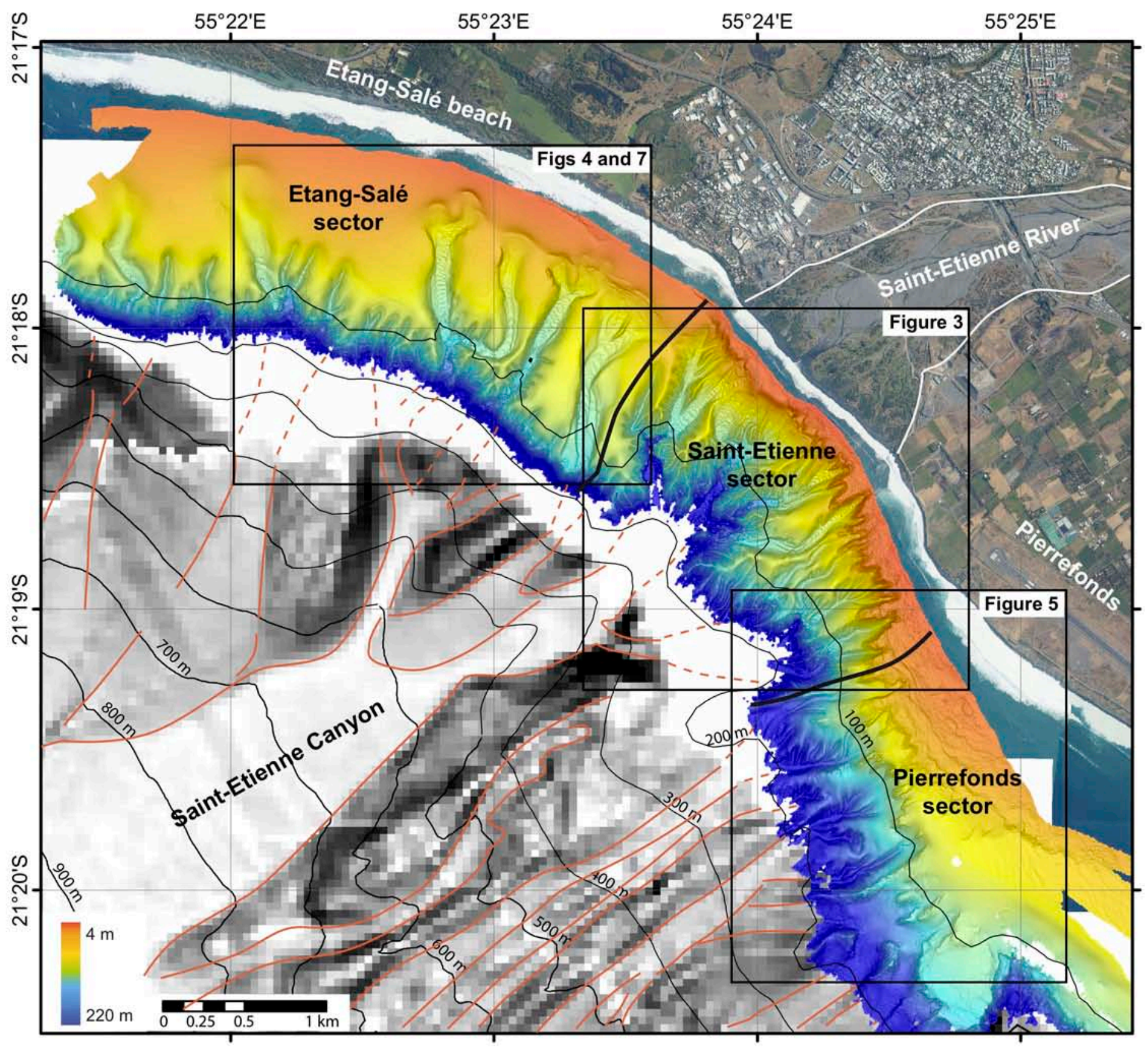

Figure 2. High-resolution BATHYBAB bathymetric map from 4 to $200 \mathrm{~m}$ water depth (in colour) superimposed to ERODER bathymetric data (slope map in grey scale, horizontal resolution $50 \mathrm{~m}$, isobaths every $100 \mathrm{~m}$ ), and to the 2008 aerial photography (OIGN) onshore. Red lines indicate the main morphological structures in the deep area; black bold lines are the morphological limits of the three coastal sectors. 

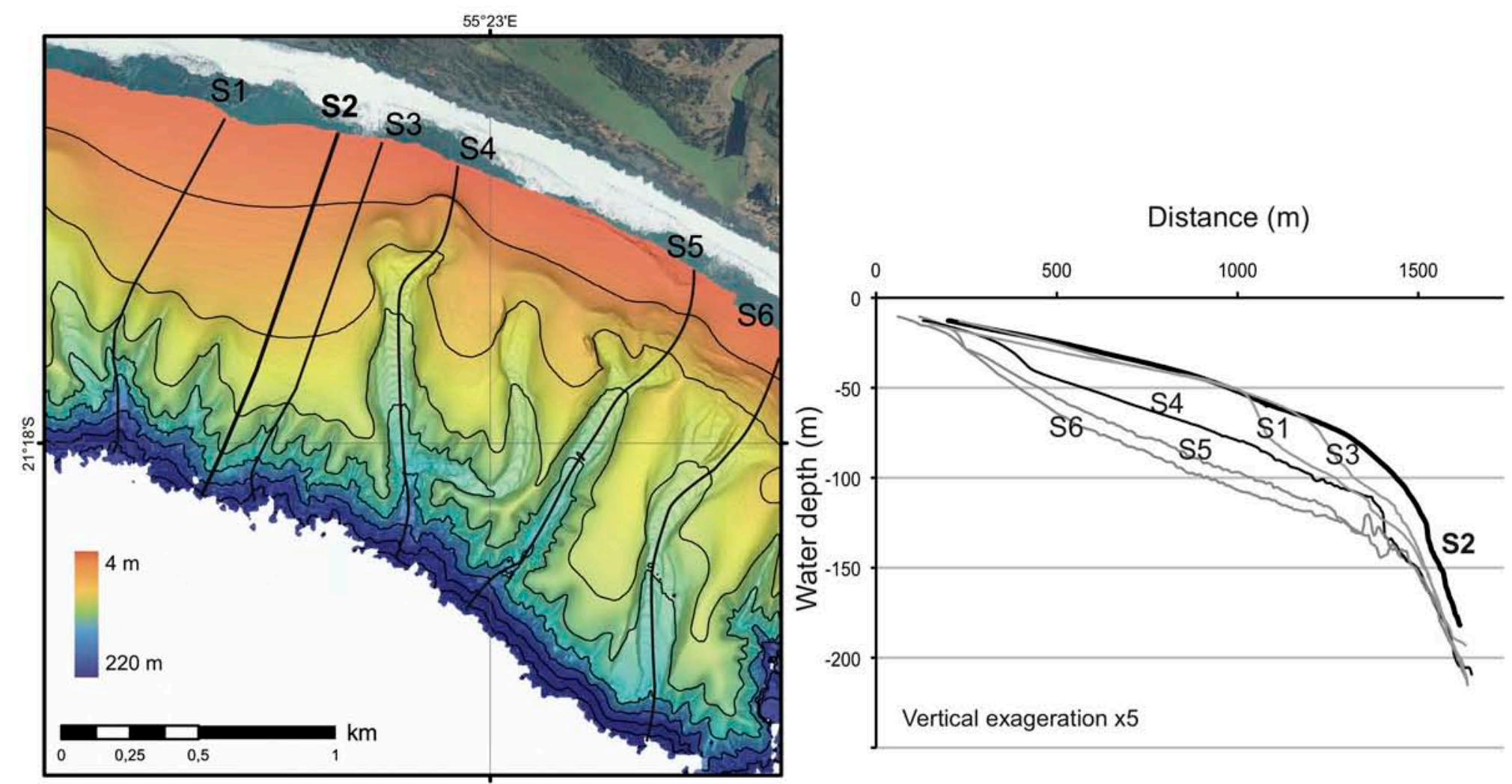

Figure 3. Bathymetric map focused on the Etang-Salé sector (isobaths every $20 \mathrm{~m}$ ), and longitudinal depth profiles (S1 to $\mathrm{S} 6$ ). $\mathrm{S} 2$ is a reference profile located outside canyon incision. 

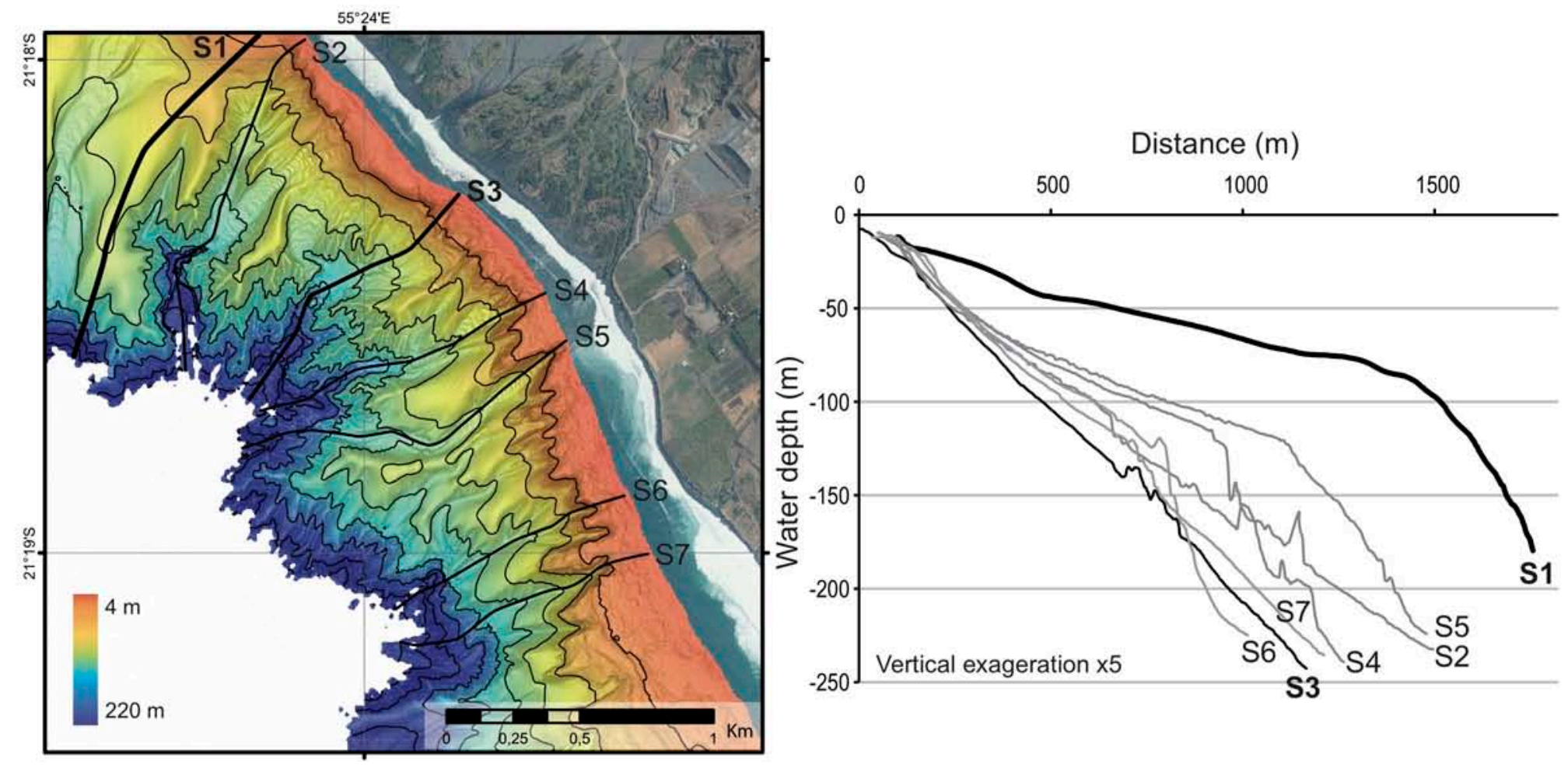

Figure 4. Bathymetric map focused on the Saint-Etienne sector (isobaths every $20 \mathrm{~m}$ ), and longitudinal depth profiles (S1 to S7). S1 is a reference profile located outside the canyon incision 

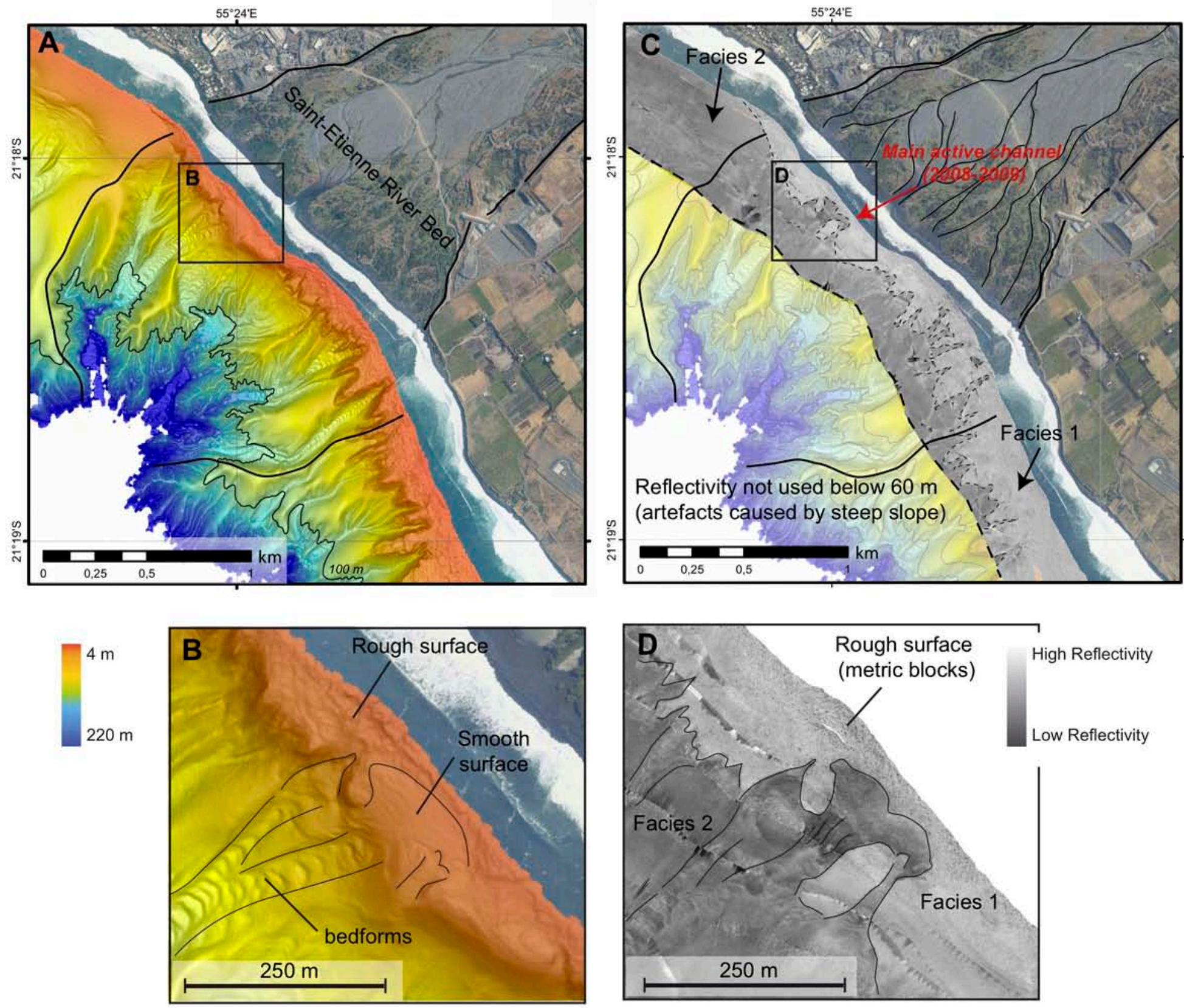

Figure 6. (A) Bathymetric map in front of the Saint-Etienne river mouth (isobath at $100 \mathrm{~m}$ ), (B) zoom of the bathymetric map at the mouth of the main river channel, $(\mathrm{C})$ refectivity map showing the reflectivity above $60 \mathrm{~m}$ water depth in front of the Saint-Etienne river mouth, (D) zoom of the reflectivity map at the mouth of the main river channel. 


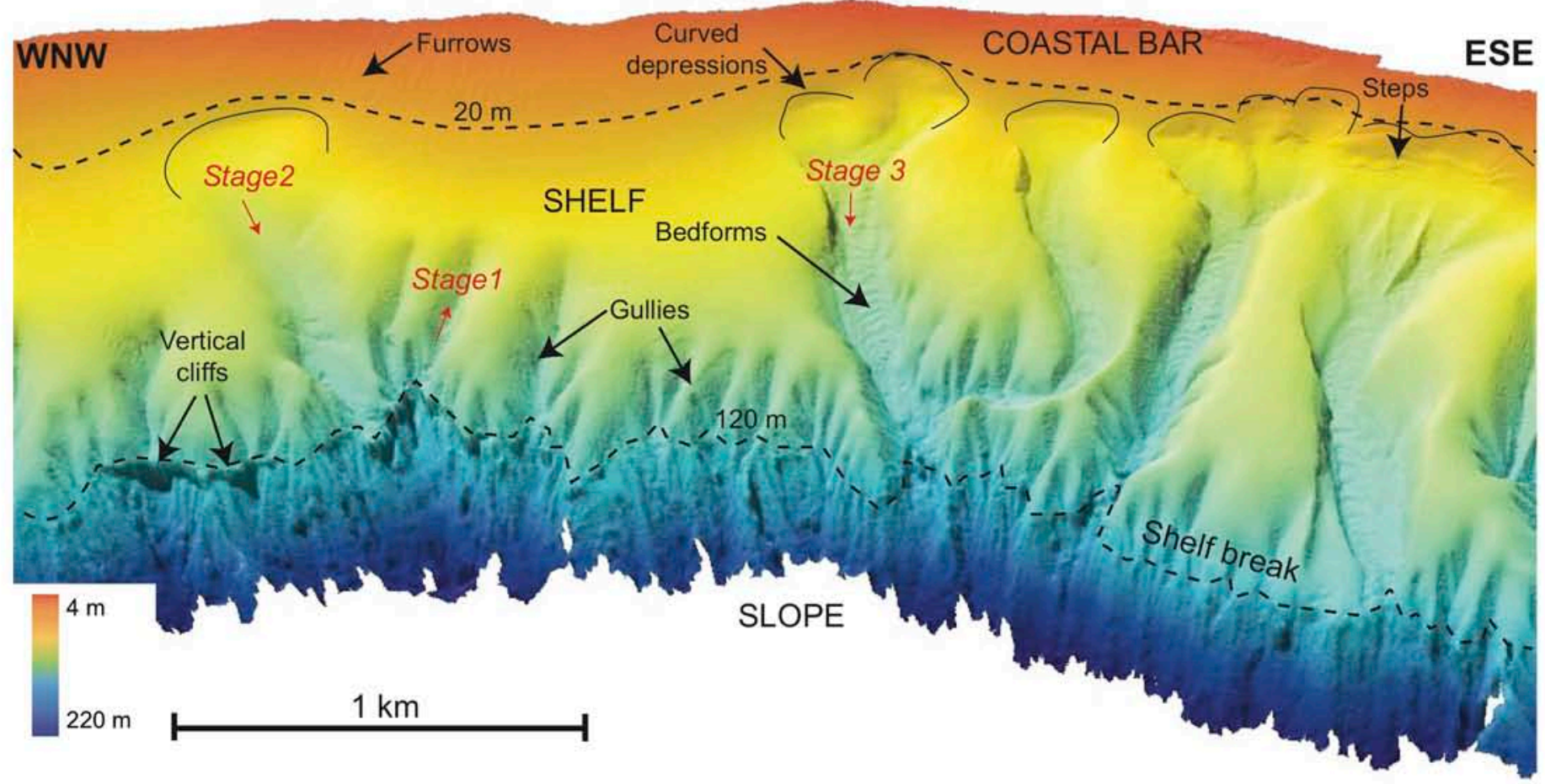

Figure 7. 3D view of the canyon heads of the Etang-Salé area (vertical exaggeration $\times 3$ ), isobaths at $20 \mathrm{~m}$ and $120 \mathrm{~m}$ are indicated. The interpretation of the different stages of canyon formation is indicated in red. 


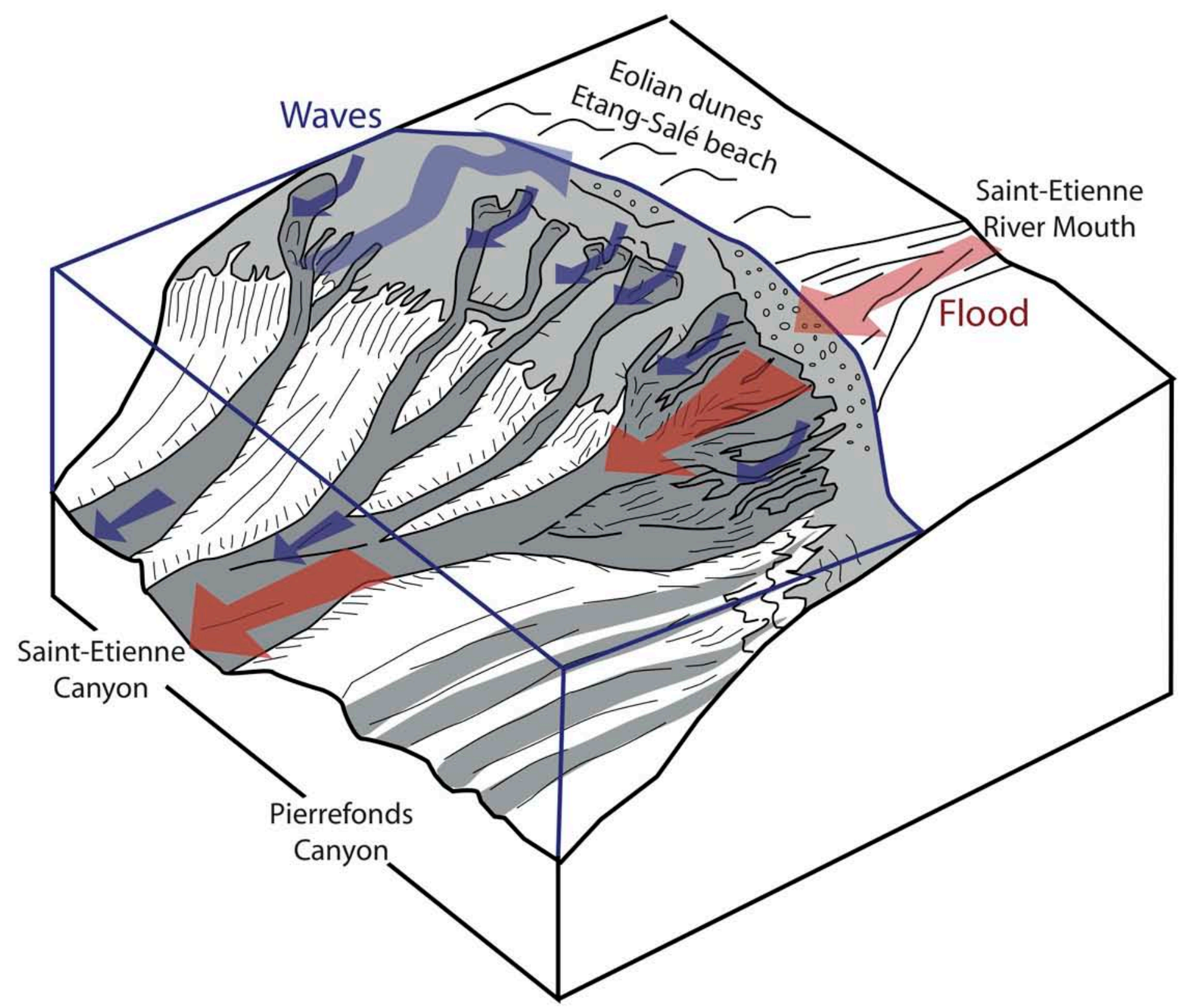

Figure 8. Schematic illustration of the land-sea transition showing the factors controlling canyon feeding and turbidity currents. Red arrows indicate processes induced by river flood generating hyperpycnal flows and blue arrows show processes generated by storm waves (austral storms or tropical cyclones). 